\title{
Humboldt térképészeti munkássága
}

\author{
Papp-Váry Árpád
}

DOI: $\underline{\text { https://doi.org/10.30921/GK.72.2020.1.2 }}$

Absztrakt: Humboldt 1798-ban Párizsba utazott, ahol találkozott Aimé Bonpland orvossal és botanikussal, aki útitársa lett utazásukon. Madridban megkapták a király engedélyét, hogy a közép-és dél-amerikai gyarmatokra mehessenek. Cumanában (ma Venezuela) szálltak partra. Csónakkal végrehajtott útjukkal bebizonyították, hogy az Orinoco és az Amazonas vízrendszerét összekötố Casiquiare folyó két irányban is folyik (bifurkáció). Az út végén, Bonpland megbetegedett. A háromheti kényszerü pihenố idố alatt Humboldt megrajzolta az Orinoco térképét. Mexikóban Humboldt megszerkesztette Új-Spanyolország térképét. 1817-ben Humboldt kiadott egy térképet, amelyen az azonos hốmérsékletû́ pontokat egy vonallal kapcsolta össze. 57 évesen elhatározta, hogy az anyagi világot egyetlen müben fogja megjelentetni. A mü címe Kozmosz. A leírások mellett szükség volt a természeti világ grafikus bemutatására is. Humboldt javasolta Berghausnak, hogy készüljön atlasz a fizikai világról. A világ elsố tematikus atlasza a Kozmosz elsổ kötetének a megjelenési évében 1845-ben jelent meg. Az atlasz címe Fizikai atlasz.

\begin{abstract}
In 1798, Humboldt travelled to Paris. There he met Aimé Bonpland, the botanist and physician who became his companion for their voyage. In Madrid Humboldt obtained permission from the King to visit the Spanish colonies in Central and South America. They landed at Cumana (today, Venezuela). They travelled by canoe south through dense tropical forests and proved that the Casiquiare River formed a connection (bifurcation) between the vast river systems of the Amazon and the Orinoco. At the end of the road Bonpland succumbed to a severe bout of fever. During the threeweek rest period, Humboldt drew map of Orinoco. In Mexico Humboldt created a map of New Spain. In 1817 Alexander von Humboldt was the first to use isothermal lines in mapping temperature. At the age of 57, he decided to write the whole physical world in one book. The title of the book is Cosmos. There was also a need for a graphical presentation of the natural world. Humboldt advised Heinrich Berghaus to map the material of the Cosmos. The world's first thematic atlas appeared in the same year as the first volume of Cosmos (1845). The title is Physical atlas.
\end{abstract}

Kulcsszavak: barométeres magasságmérés, élettelen környezet, bifurkáció, Új-Spanyolország térképe, izotermavonal, fizikai atlasz Keywords: barometric height measurement, lifeless environment, bifurcation, Map of New Spain, isothermal lines, physical atlas

Humboldt halálának 100 éves évfordulóján 1959-ben a Földrajzi Közlemények 3. és 4. számában egyegy cikk emlékezett meg Humboldt munkájáról. A cikkeket a Magyar Földrajzi Társaság alelnökei, Bulla Béla és Radó Sándor írták. Mindketten megemlékeztek az izotermavonalak felfedezésérốl mint Humboldt térképészeti újításáról. Radó megemlíti a Humboldt által készített Mexikótérképet szakmai értékelés nélkül. A Nemzetközi Térképészeti Társulás (ICA) közremû́ködésével a 20. század vége felé kiadtak egy könyvet a térképészeti újdonságokról, az 1900-ig kialakult új térképészeti fogalmakról. (Ed.: Wallis $\square$ Robinson, 1982). A kiadvány Humboldtnak egyetlen térképészeti újítását az izotermákat ismerteti. A közelmúltban megjelent A természet feltalálója, Alexander von Humboldt kalandos élete címû́ mû (Wulf 2017) is csak az izotermákat említi Humboldt térképészeti munkájaként.

Ha egyéb térképészeti újítása nem is volt, de az útja során térképeket akart készíteni. Ezt jelzi, hogy útja elôtt Zách Ferenc javaslatára számtalan térképkészítéshez szükséges mûszert rendelt Londonból, és gyakorolta azok kezelését. Ezért utazását és annak eredményeit feldolgozó munkáit a tanulmány ebbốl a szempontból értékeli.

\section{Humboldt útja az Újvilágba}

Humboldt kora ifjúságától tervezte távoli, ismeretlen földek megismerését. Ezen elképzelésének az elôkészítése keretében 1795-ben Svájcba utazott, és útja során barométeres magasságmérések alapján megrajzolta Genova és a Szt. Gotthárd-hágó közötti út metszetét. 1796-ban édesanyja halálával jelentôs örökséghez jutott. Otthagyta az állami szolgálatot, hogy korábbi célját megvalósíthassa. A nagy utazás elốtt, 1797-ben Jénában megismerkedett Zách Ferenc magyar asztronómussal, a közeli seebergi obszervatórium igazgatójával. Zách a gothai hercegtôl kapott megbízást csillagvizsgáló létesítésére. Zách tanácsára és irányításával asztronómiai, topográfiai és meteorológiai mûszerek használatát gyakorolta. Megtanulta az akkor legújabb Hadley-féle tükörszextáns kezelését is. Az asztronómiai, topográfiai múszerek ismeretére azért volt szüksége, hogy földrajzi helymeghatározásokat végezzen új térképek szerkesztéséhez, vagy a korábbiak helyesbítéséhez. Késốbb készített térképein a földrajzi hosszúságot a párizsi délkörtốl számította.

Utazásának fố célja, egyik utazása elốtti búcsúlevele szerint „a szemeim mindig az erốk együttmûködését, az élettelen környezetnek a hatását az élố növény- és állatvilágra, a természet harmóniáját fogják vizsgálni.” (Radó 1959, p. 324.) Külföldi útjára több szextáns mellett kronométereket, barométereket, összesen több mint 40 mû́szert vitt magával. A barométerek közül csak egy tartott ki az út végéig, a többi útközben összetört. Amerikai útján 257 csillagászati helymeghatározást végzett, és 453 alkalommal mért magasságot. (Vécsey 1967 , p. 20.). 
1798-ban Párizsba, a természettudományok akkori központjába utazott, ahol Zách ajánlólevelei segítségével a tudományos körök figyelmét fel tudta kelteni tervei iránt. A forradalmi francia köztársaság és az európai királyságok közötti harcok miatt nem tudott útnak indulni. Amikor a spanyolok kiléptek a franciák elleni koalícióból, elhatározta, hogy Dél-Amerikába próbál eljutni. Kiválasztott útitársával, Aimé Bonpland orvossal és botanikussal Spanyolországba utazott, hogy szerencsét próbáljon a spanyol udvarnál.
Az útra Marseille-ból indultak hajóval. Az Ibériai-félsziget déli partjáról Madridba utaztak. Itt az udvarban megkapták IV. Károly király engedélyét, hogy saját költségükön a közép- és dél-amerikai spanyol gyarmatokra mehessenek. Ebben az időben ezekre a területekre csak spanyol hivatalnokok és a katolikus miszsziók tagjai utazhattak. Az engedély birtokában Humboldt és Bonpland folytatták útjukat $\mathrm{A}$ Coruñáig. Az út során, a Földközi-tengertôl az Atlanti-óceánig, Humboldt meghatározta több jelentôs pont földrajzi

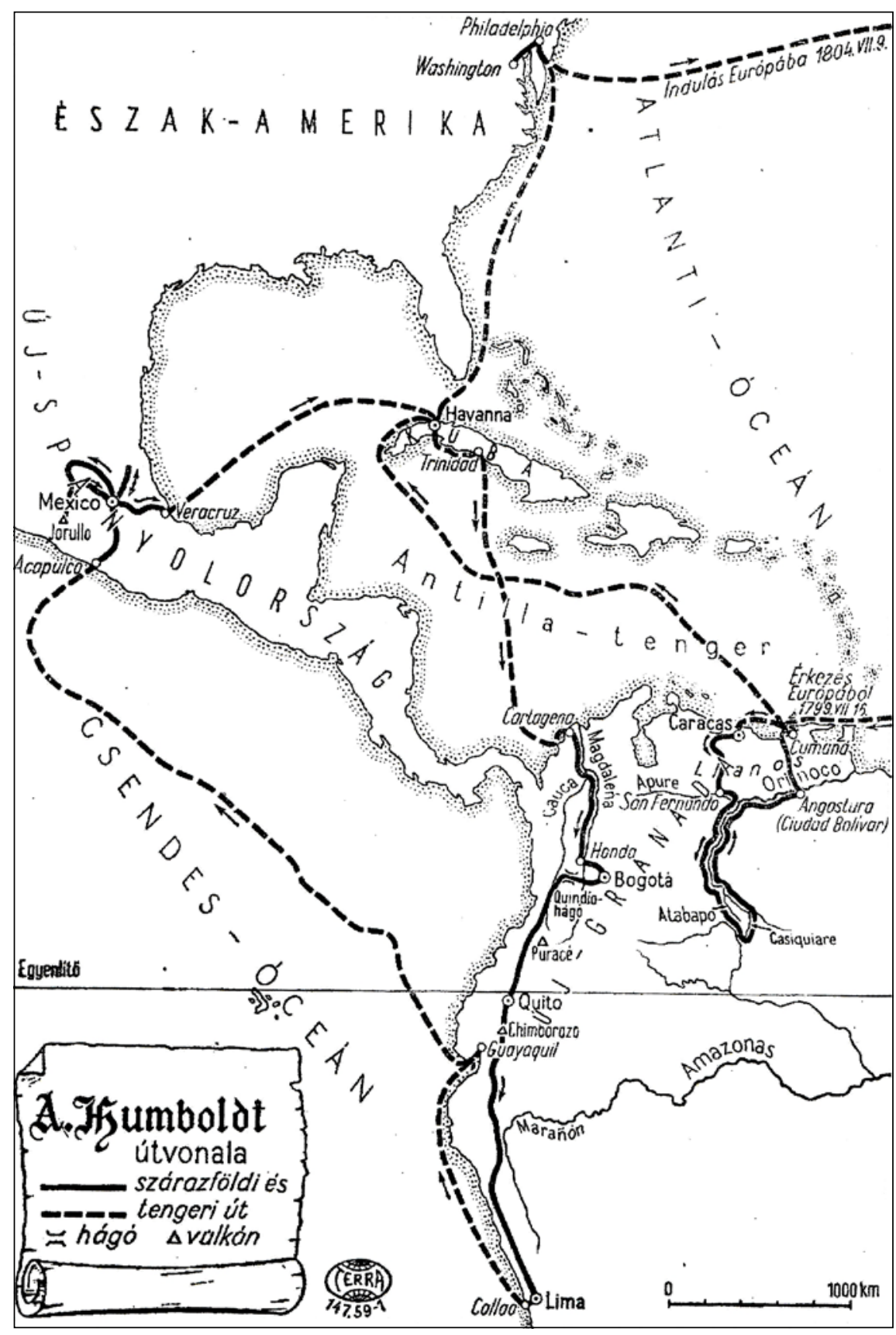

1. ábra. Humboldt amerikai útja (Radó 1959)

helyzetét, és barométeres magasságméréseket végzett. Ennek eredménye az első barometrikus magasságméréssel nyert metszetrajz, amely bizonyította, hogy az Ibériai-félsziget egy magas plató.

A Coruñából a Pizarro nevú vitorlás hajó fedélzetén indultak el Havannába. A hajó megállt a Kanáriszigetekhez tartozó Tenerifén. Itt felmásztak a Pico de Teyde 3700 méter magas csúcsára. Humboldt metszetrajzon szemléltette a különbözó növények elôfordulását. Az indulástól számított 38. napon, az eredeti úti cél, Havanna helyett, a hajón kitört tífuszjárvány miatt, Cumanában (ma Venezuela) szálltak partra. Már a XVII. század óta a jezsuita híradásokból ismert volt, hogy az Orinoco felső folyása a Rio Negróval, az Amazonas egyik mellékfolyójával a bifurkáció révén (amikor egy folyó kétfelé ágazik), összeköttetésben van. Humboldt elhatározta, hogy ellenórzi ezt az állítást.

Csónakkal végrehajtott útjukkal bebizonyították, hogy az Orinoco és az Amazonas vízrendszerét összekötő Casiquiare folyó két irányban is folyik, az Orinoco és az Amazonas folyamterületei összefüggenek. Útjuk során 10 hét alatt $2800 \mathrm{~km}$ hosszú utat tettek meg ezer veszély közepette (Humboldt 1861). A bifurkáció kimutatása jelentôs földrajzi eredménye útjuknak. Az út végén, az Orinoco menti Villa la Angosturában (ma Ciudad Bolívar) Bonpland megbetegedett. Humboldtot is megviselték a trópusi viszonyok, reumás lett. Késôbbi levelezésében arra hivatkozik, hogy ezért nehéz elolvasni a kézírását. A háromheti kényszerú pihenó idố alatt Humboldt megrajzolta az Orinoco térképét. A kéziratos rajz ma Krakkóban (Biblioteka Jagiellońska) van. Az elsố ismertetés a térképrôl német folyóiratban jelent meg (Leitner 2001). Érdekes, hogy a mostoha körülmények között rajzolt térkép szakmai elismerése, értékelése mind ez ideig elmaradt.

A dél-amerikai tengerpartról Havannába hajóztak, és három és fél hónapot töltöttek a szigeten. Kuba után Új-Granadában (a mai Kolumbia, Venezuela, Ecuador területén) és 


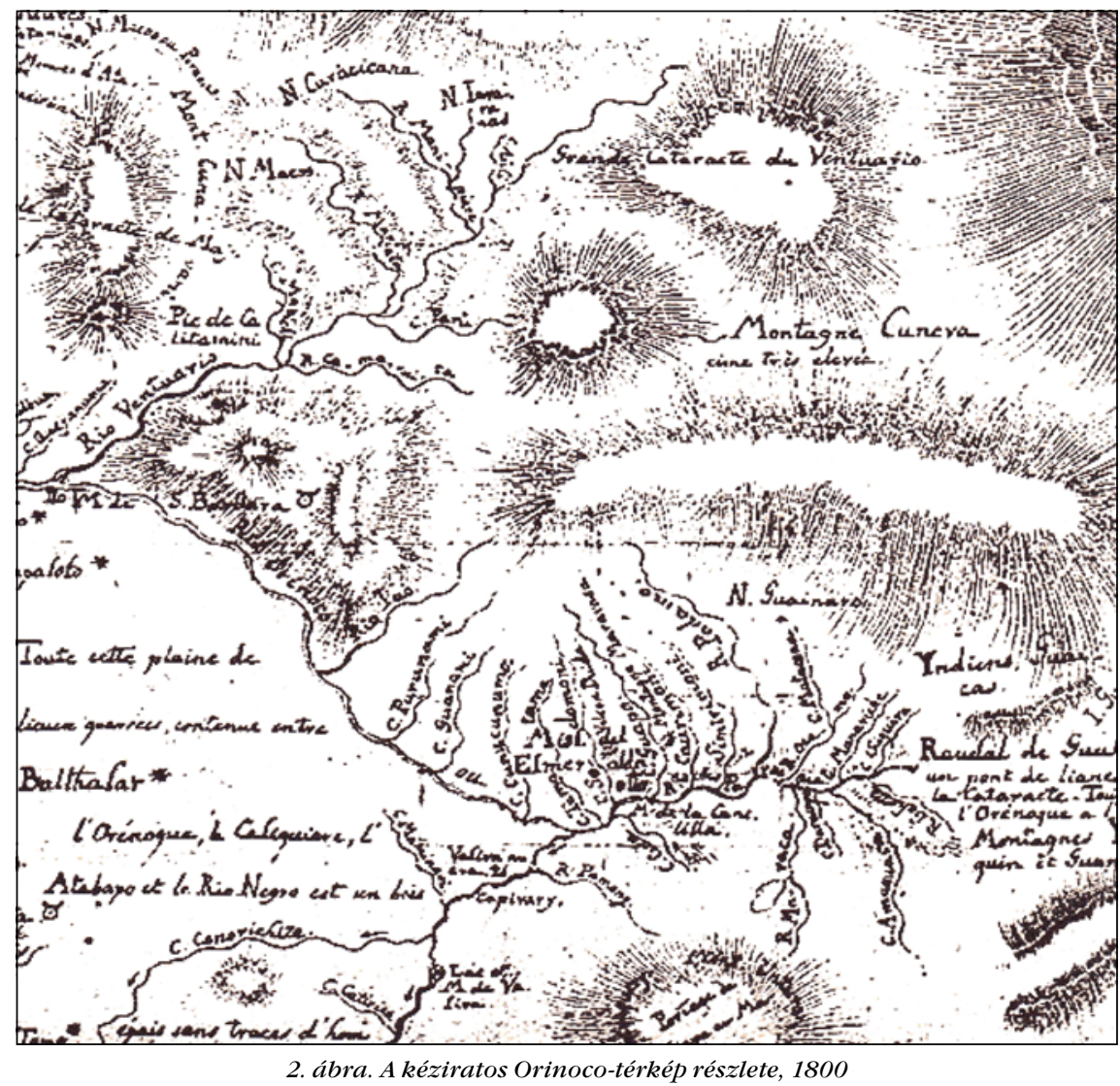

Peruban az Andok hegyeit tanulmányozták. E közben, a Chimborazo megmászásakor, az egymást váltó növényzeti övek keresztezése olyan érzést váltott ki Humboldtban, mintha az Egyenlítôtôl tartana az Északi-sark felé. A magassággal változó növényzeti zónákat látva megállapította, hogy a klíma és a tengerszint feletti magasság a növények elterjedésére meghatározó befolyással van. Itt vált tudatossá benne a természeti tényezók szoros összekapcsolódása. Új természetlátomását, Naturgemäldének (természetfestménynek) nevezte, és a hegy színes metszetrajzával szemléltette a magassággal változó növénytársulásokat. A grafikus megoldással az volt a célja, hogy a természeti tényezók összefüggéseit gyorsan, áttekinthetôen lássák az emberek. A hegy növényzeti zónáiról készített rajza késóbb több hegy földrajzi, növénytani leírásának lett a mintája. A tengerpartra érve, Limából Új-Spanyolország központjába, Mexico városába igyekeztek. Egy évet töltöttek a városban és környékén. A spanyol korona vendégeként engedélyt kapott a felfedezók korábbi beszámolóinak, a meglévô térképeknek és az indián emlékeknek a megtekintésére.

Humboldt és Bonpland 1804. július 9-én kezdte meg a hajóutat vissza Európába, amelynek földjére augusztus 3-án Bordeaux-ban léptek. Véget ért az 5 évig és 2 hónapig tartó út.

\section{Az utazási eredmények feldolgozása}

Richthofen azt írta, hogy „Humboldt a megfigyeléseknek, adatoknak, térképvázlatoknak, rajzoknak olyan tömegét hozta magával, mint elôtte egyetlen utazó sem." (Vécsey 1967, p. 20.) Az Európába hozott anyag feldolgozása több évtizedet vett igénybe. Tíz nagy alakú és húsz kisebb alakú kötet tartalmazza a leírásokat, melyek francia nyelven 1805 és 1839 között Bonpland 1799 és 1804 között az Újvilág trópusi vidékein véghez vitt utazásának leírása" címen. Az utazásáról szóló beszámoló egyes részei másmás címen többféle kiadásban is megjelentek. Két kötet címében az atlasz szó szerepel. Az egyik kiadás címe: „Atlas géographique et physique du royaume de la Nouvelle-Espagne, jeletek meg „A. v. Humboldt és Aimé
1808-1811" (Új-Spanyolország földrajzi és fizikai atlasza). A másik kiadásé „Atlas géographique et physique des régions équinoxiales du Nouveau Continent, fondé sur des observations astronomiques, des mésures trigonométriques et des nivellemens barométriques par Al. de Humboldt, 1814-1838" (Az Új Kontinens földrajzi és fizikai atlasza csillagászati megfigyelések, trigonometriai mérések és barometrikus szintezések alapján).

Napjainkban az atlasz szó a könyvszerú, egységes térképgyújteményeket jelenti. Humboldt munkájában a szöveges anyag a meghatározó, azt csak néhány térkép és ábra színesíti. Az atlasz kifejezést Mercator alkotta meg saját munkája elnevezéseként, amely azonban már halála után, 1595ben jelent meg. Mercator és követối XVI. századi atlaszaiban a térképek hátoldalait az ábrázolt területrôl szóló földrajzi leírásokkal töltötték ki. Ezért nem tarthatjuk meglepőnek, teljesen szokatlannak az atlasz szó használatát Humboldt útleírásának a címeként. Ez a címhasználat megerôsíti azt a feltételezést, hogy évekkel később, 1845-ben, a világ első tematikus világatlaszának a címe, a Fizikai atlasz, Humboldt javaslatára született.

Az egyik kötetben közölte az Amerikáról készült elsô térképet, Juan de la Cosa 1500. évi munkáját. A térkép mellett ismertette készítőjének életútját, hangsúlyozva a térkép jelentôségét az új földrész megismerésében. A térképet fakszimilében is kiadta 1853ban, és ez jól mutatja, milyen fontosnak tartotta ezt a múvet.

A kötetek mellett Humboldt számtalan tanulmányt közölt az utazás egyes részeredményeirôl. Humboldt elōtt már a Föld több pontján mérték a hômérsékletet, de ezeket a táblázatokba foglalt adatokat nehéz volt összehasonlítani. Humboldt ötlete volt, hogy az azonos hômérsékletú pontokat egy vonallal összekapcsolja. A növényzeti formákról szóló 1816 ban közölt tanulmányában írta le elgondolását, de a vonalnak még nem adott nevet, és a cikkhez még nem mellékelt térképet. A következő évben megjelent munkájának már a címébe 


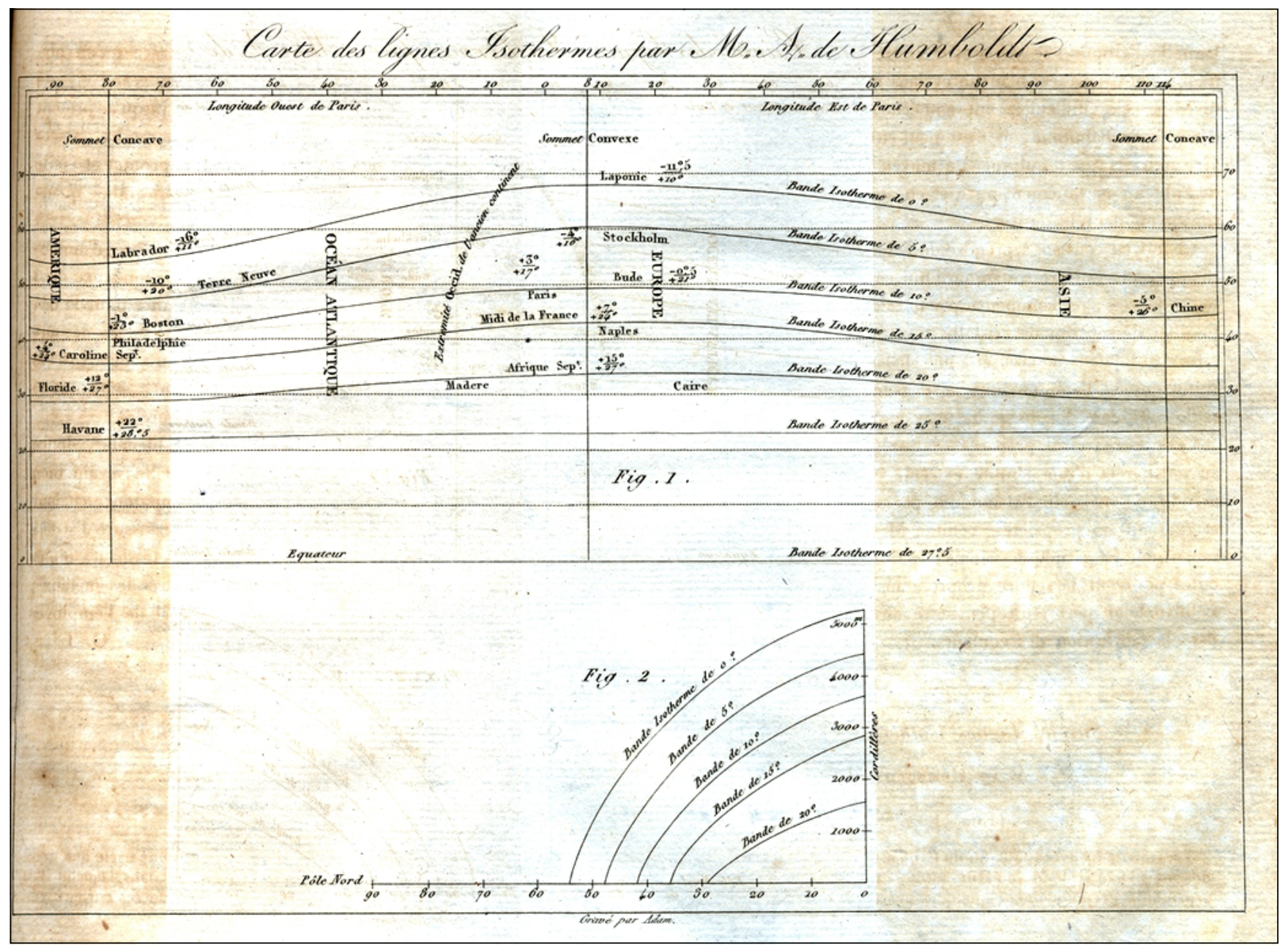

3. ábra. Humboldt izotermavonalas ábrája, 1817.

is befoglalta új ábrázolási módszerének a nevét. A munka címe magyarul: Az izotermákról és a hô elosztásáról a földgolyón. (Robinson-Wallis 1967).

A szövegben hangsúlyozta, hogy vonalai nagyon hasonlóak Edmond Halley 1701. évi térképén szereplô izogonvonalakhoz. Ezen munkájához sem csatolt térképet. Még abban az évben egy másik folyóiratban jelentette meg az izotermavonalakat mutató rajzát. Ezen öt-öt Celsius-fok különbséggel hét izotermavonalat rajzolt az északi féltekére, Észak-Amerikától Kelet-Ázsiáig. A partvonalakat nem rajzolta meg, csak az izotermavonalak mellé írt néhány településnév helyzete érzékelteti a térbeliséget (Wallis-Robinson 1982). A tudományos világ hamar felismerte a módszer jelentôségét és alkalmazhatóságát. Rövidesen kiadták a francia tanulmány fordításait és néhány izotermát szemléltetô térképet is. Humboldt elképzelésének az igazi elismertséget Heinrich Berghaus Fizikai atlasza hozta. Az 1845-ben megjelent atlasz elsó térképe a Földön szemléltette az izotermákat a következó címen: Az izotermavonalak Humboldti rendszere Mercator-vetületben. Az atlasz második térképe is izotermavonalakat ábrázolt az északi féltekén, poláris vetületben, Humboldt 1818. évi térképét is felhasználva. Az izotermaábrázolás általánossá válása nyomán a késóbbi tudománytörténeti munkákban Humboldtot az éghajlati térképezés atyjának nevezték el.

Az utazás eredményeinek a feldolgozása során Humboldt saját szerkesztésú térképpel kísért politikai tanulmányt írt Kubáról. A kubaiak annyira elismerik munkájának eredményeit, hogy 1939-ben a Humboldt Egyetem elōtt felállított fehér márvány szobrára emléktáblát helyeztek el Al Segundo Descubridor de Cuba (Kuba második felfedezóje) felirattal.
Humboldt útleírásának térképeit, ábráit sok szerző átvette saját munkájába, néha hivatkozva is a szerzôre. A mi szempontunkból az amerikai William Channing Woodbridge (1794-1845) munkássága az érdekes. Humboldt leírásai alapján ő több térképet szerkesztett földrajzi tankönyveihez. A térképeken mindig feltüntette, hogy munkája Humboldt leírásán alapul. Már több térkép megjelenése után, 1827-ben európai tanulmányútján Párizsban felkereste Humboldtot, és késôbb is leveleztek egymással.

\section{Új-Spanyolország térképe}

Humboldt 1804-ben és 1809ben tanulmányt jelentetett meg Új-Spanyolországról, amelybe maga szerkesztette térképet illesztett. A szövegben leírta, hogyan készült a térkép. Felsorolta azokat a kéziratos és nyomtatott térképeket, amelyeket látott és ezen belül azokat, amelyeket 
fel is használt térképe készítésekor. A mai Mexikóváros tágabb környékén több pont földrajzi koordinátáit határozta meg csillagászati módszerrel. E mellett, háromszögeléses felmérést és barometrikus magasságméréseket végzett. A távolabbi területeken csak magasságmérést és kronométeres hosszúságmeghatározást készített. Külön táblázatba foglalta azokat a pontokat, amelyeknek az általa meghatározott földrajzi koordinátáit megfelelônek tartotta. Ez a térképkészítés gyakorlatában teljesen új információ volt, ilyen adatokat nem találunk másik, a XVIII. században vagy a XIX. század elején készült térképeken. Mexikóváros központjának, a városi könyvtárnak a koordinátáit különös pontossággal kívánta meghatározni. A Hold és Nap távolsága alapján, Mexikóváros és Veracruz közötti, általa végzett háromszögelésból számított távolság és a két hely idôkülönbsége alapján is meghatározta a hely földrajzi koordinátáit. Míg szélességmeghatározásai megfelelnek a mai mérési eredményeknek, a hoszszúság meghatározásainál több kilométeres eltérések adódnak. Mexikóváros központjánál is, minden erôfeszítése ellenére majdnem 5 kilométeres eltérés van a mai adatokhoz képest. Ennek ellenére a városkörnyéki terület térképe nagyon jó. A domborzat és a síkrajz ábrázolása a korabeli francia iskola gyakorlatát tükrözi, a domborzatot lendületcsíkozással szemlélteti.

A korábbi, általa is felhasznált térképekhez képest (José Antonio Alzate 1769, Aaron Arrowsmith 1803) egy feltû́nô különbség van: a Sierra Madre hegyláncot nem kettôs, hanem csak egyes hegyláncként ábrázolta. A kor általános téves felfogása volt, hogy az Andoktól északra egy hegylánc húzódik végig Amerika nyugati szélén. Humboldt inkább hitt ennek az elképzelésnek, mint a korábbi ábrázolásoknak.

Humboldt útleírásuk amerikai megjelenésének az elôszavában (1810) kifogásolta, hogy nem sokkal korábban megjelent térképének egyes részeit Arrowsmith a nevének említése nélkül átvette. Javasolta, hogy a szerzők a jövőben adják meg térképeiken a felhasznált forrásokat.
Arrowsmith 1820-g még négyszer megjelentette térképét, de nem említ forrásokat, és nem reagál Humboldt, talán nem is ismert bírálatára (Allen 2016). Késôbb Humboldt javaslatát többen megvalósították, és a források felsorolása, értékelése hozzájárult a térképészet tudományos jellegének az erôsítéséhez.

Mai szemmel Humboldt saját mérései alapján készült térképe csak Mexikó középsô részén haladja meg a pontosság szempontjából a korábbi térképeket, a többi területen lényeges javulás nem tapasztalható (Allen 2017). Az adott korban, az adott eszközökkel, felmérési módszerrel más sem tudott volna jobbat készíteni. A térkép jelentôsége, hogy felhívta a figyelmet a terület erôforrásaira, a beruházási lehetôségekre. Az 1850-es évekig ezt tartották a legfontosabb térképészeti forrásnak Mexikóról, és számtalan térkép készült ez alapján az idôközi változások feltüntetésével.

A közelmúltban a MapAnalyst program felhasználásával kiértékelték Humboldt, Alzate és Arrowsmith térképét. A program a térképeken lévô azonos pontokból kiinduló fekete vonalak hosszával és irányával jelzi a pont valóságos helyét. A kiértékelést végző szerző (Allen 2014) ironikusnak tartja cikkében, hogy Humboldt is közölt egy térképet tanulmányában, ahol a Pico de Orizaba csúcsához viszonyítva szemlélteti Mexikóváros, Acapulco, Veracruz helyzetét saját térképén és Alzate és Arrowsmith rajzain.

Szakmai szempontból érdekes, hogy az Újvilágban készült és fél évszázadig másolgatott térképet a térképészeti irodalom nem tartja kiemelkedô, példát mutató alkotásnak. Allen ennél tovább megy azt írva (2014), hogy Humboldt ezzel a munkájával nem bizonyult kartográfus újítónak.

Mexikói tartózkodása idején Humboldt földtani térképet és földtani metszeteket is készített. A földtani térképek már ismertek voltak Humboldt korában, de útleírásában javasolta, hogy a mélységre vonatkozó földtani térképek is készüljenek. A Berghaus-féle tematikus atlasz már tartalmaz mélységi metszeteket mutató ábrát.

\section{A Kozmosz. A természeti világ leírásának vázlata.}

Az utazás és az útról megjelent könyvsorozat kiadása Humboldt vagyonát majdnem felemésztette. Anyagi nehézségei miatt fel kellett adnia függetlenségét, és 1827-ben kamarás lett a porosz király mellett. Ekkor, 57 évesen elhatározta, hogy az anyagi világot egyetlen múben fogja megjelentetni. Elképzelésének bemutatására, kutatásai eredményeinek közkincscsé tétele érdekében a berlini egyetemen elóadássorozatot kezdett. A 61 elôadásnak óriási sikere volt. Ezeket kibóvítve, átdolgozva könyvben is meg kívánta jelentetni. Az elképzelt mú címe Kozmosz, a természeti világ leírásának vázlata. A szépséget és rendet jelentô görög kozmosz szó Humboldt értelmezésében a Világmindenséget, az eget és a földet jelenti. A nagy mú elsố kötete 1845ben jelent meg. A következó években 10 nyelven is kiadták, köztük 1857 ben magyarul is megjelent. Az elsô kötet kiadása után még négykötetnyi anyagot írt. A második kötet 1847ben, a harmadik 1850-ben, a negyedik 1858-ban jelent meg. Két nappal az ötödik kötet kéziratának a befejezése után Humboldt élete 89. évében meghalt (Wulf 2017). Ez a kézirat 1862-ben jött ki a nyomdából. A részletes leírások mellett szükség volt a természeti világ grafikus bemutatására is. Heinrich Berghaus (17971884) vállalkozott a Kozmosz anyagának térképi formába öntésére.

\section{Az elsố tematikus atlasz}

Berghaus felmérést tanult, majd a porosz hadsereg földrajzi mérnökeként közremúködött az ország háromszögelési hálózatának mérési munkáiban. Katonaként részt vett a Napóleon elleni harcokban. Berghaus a háború befejezésekor csapatával Párizs közelében, Saint Germaineben táborozott. Amikor meghallotta, hogy K. F. Müffling tábornok meglátogatja Humboldtot, megkérte, hogy elkísérhesse a találkozóra. Másnap, 1815. augusztus 18-i reggeli jelentkezésekor a tábornok közölte, egyéb parancsnoki megbeszélések miatt 
nem tud menni, vigyen el egy levelet Humboldthoz. Ekkor találkoztak elôször. Tartós és folyamatos kapcsolatuk 1825-ben kezdôdött. Ettôl kezdve Humboldt haláláig, 1859-ig leveleztek egymással. Berghaus Humboldt neki írt leveleit megốrizte, és később 1863-ban, három kötetben közzé is tette (Humboldt 1863). A levelezés bevezetôjében írja le az elôbb említett elsố találkozásukat. A 33 éven át tartott levelezés bizonyítja szoros kapcsolatukat.

Berghaus 1821-1854 között felmérést tanított Berlinben. Elsố térképei az általa alapított Hertha címú földrajzi folyóiratban (1825-1829) jelentek meg. 1835-ben atlaszt készített Ázsiáról. Ezzel a munkával vált általánosan ismertté. Tervezte egy földrajzi múvészeti iskola (Geographische Kunstschule) alapítását. Ebben Humboldt sietett segítésére. Anyagi támogatásával létrejött a földrajzi múvészeti iskola Potsdamban, 1838ban. Humboldtnak már nagy utazása elôtt az volt az elképzelése, hogy az ismeretek átadásának legjobb módja a tudományos megállapítás múvészi képbe illesztése, más szavakkal, grafikai megformálása. Ezt alkalmazta az Andok magashegységi növényzeti zónáinak a bemutatásánál. Érdekes egybeesés, hogy Berghausnak is ez volt a véleménye a tudomány és a múvészet összekapcsolásáról, hangoztatva, hogy a grafikus kép üzenetét nemcsak gyorsabban, de tartósabban is megjegyezzük. A földrajzi múvészeti iskola megalkotását mindkettőjük elképzelései gyakorlati megvalósításának tekinthetjük.

Egyesek feltételezik, hogy Humboldt a földrajzi múvészeti iskola elókészítése során javasolta Berghausnak, hogy készüljön atlasz a fizikai világ bemutatására, a Kozmosz illusztrálására. Ennek nincs írott nyoma, de a Kozmosz második, Stuttgartban sokszorosított kötetének a végén van egy prospektus, ami megerôsíti az atlaszhoz kötôdô kapcsolatukat. Berghaus a Kozmosz megírásával párhuzamosan megkezdte atlasza térképeinek a szerkesztését. Humboldtnak a készülő atlasz iránti érdeklődését jól jelzi, hogy annak készülésérôl az uralkodókat (III. és IV. Frigyes Vilmost) személyesen tájékoztatta és az elkészült próbanyomatokat bemutatta. Berghaussal folytatott levelezésébôl kitûnik, hogy nagy figyelemmel kísérte a térképészeti munkákat. Név szerint ismerte a legjobb térképmetszőket. Információkkal és tanácsokkal is támogatta a kartográfiai tevékenységet. Nem csak követte ezeket a munkákat, hanem befolyásolta is (Pápay 1995).

A kinyomtatott atlasz elsô kötete a Kozmosz elsô kötetének a megjelenési évében, 1845-ben, a második kötet 1848-ban jelent meg. Az atlasz kiadója a gothai Justus Perthes cég volt. Az atlasz címe egyszerúen csak Fizikai atlasz vagy térképgyújtemény (Physikalischer Atlas oder Sammlung von Karten). Ez volt az elsố tematikus atlasz. Elsố alkalommal jelent meg egy olyan mú, amelyben a Föld különböző fizikai tényezőit földrajzi térképek szemléltették. A 27×38,4 cm nagyságú, vonalas és felületi színeket használó kétkötetes atlasz 92 oldalon 75 térképet tartalmazott. A természeti jelenségeket nyolc csoportba sorolták. Az elsô kötet csoportjai a meteorológia, hidrológia, geológia, földmágnesség és növényvilág. A második kötet három témaköre az állatvilág, emberföldrajz és néprajz.

A Fizikai atlaszt 1850 -ben követte annak kisebb formátumú, $17,5 \times 24,5 \mathrm{~cm}$ nagyságú, 28 rézmetszésú, színezett térképoldalt tartalmazó iskolai változata, a Physikalischer Schul-Atlas. (Ezt az atlaszt a gothai Jurtus Perthes vállalat NDK-beli utódvállalata, a VEB Hermann Haack kiadó, a cég alapításának 200 éves évfordulóján, 1985 ben reprint változatban megjelentette.) Az iskolai atlasz térképein a bal felsố sarokban olvasható a megjegyzés, hogy a fizikai atlaszból átvett térképrôl van szó. A jobb felsố sarokban lévô megírás a térkép sorszámát jelöli. Az atlasz elején, a térképek elôtt, rövid leírás olvasható az egyes térképekrôl. Ezt a szöveges részt a Fizikai atlasz teljes tartalomjegyzéke zárja. A két tartalomjegyzék egybevetéséból megállapítható, melyik térképeket vették át az iskolai változatba. Az iskolai atlasz egy helyen tünteti fel Humboldt nevét. Az Andok öt magas hegyének (Aconcagua, Sajama, Chimborazo, Cotopaxi, Popocatapetl) növényzeti zónáit szemléltető metszet aláírása felsorolja a rajzok szerzóit: Humboldt, Bonpland, Pentland. (Pentland ír földrajzos volt, aki 1826-1827-ben térképezte a bolíviai Andokat.)

\begin{tabular}{|l|c|c|}
\hline \multicolumn{1}{|c|}{ Fejezetcím } & $\begin{array}{c}\text { Nagy } \\
\text { atlasz }\end{array}$ & $\begin{array}{c}\text { Iskolai } \\
\text { atlasz }\end{array}$ \\
\hline Éghajlattan & 13 & 5 \\
\hline Vízrajz & 16 & 4 \\
\hline Földtan & 15 & 6 \\
\hline Földmágnesség & 5 & 3 \\
\hline Növényvilág & 8 & 4 \\
\hline Állatvilág & 12 & 3 \\
\hline Emberföldrajz & 4 & \\
\hline Néprajz & 19 & 3 \\
\hline Összesen & 92 & 28 \\
\hline
\end{tabular}

Az atlaszok tartalmának az összehasonlítása térképoldalak száma szerint

Humboldt gondolatainak vizuális megjelenítése óriási siker volt. Másolták, plagizálták, utánozták sok kiadványban. Miért lehetett többféle atlaszt, térképet és ábrát hivatkozás nélkül megjelentetni minden következmény nélkül? Ennek az az oka, hogy a szerzối jog a XIX. század közepéig nem létezett. A szerzô belátására volt bízva, hogy hivatkozik-e az általa átvett gondolat, vagy rajz alkotójára. Poroszországban például csak 1849-ben lépett életbe a szerzói jogi törvény (Wulf 2017, p. 232.). Ennek megismerése és gyakorlati alkalmazása, általánossá válása hosszabb időszakot igényelt.

Idôben talán a legkorábbi, azonos címú, több térképet átvevő kiadás, Berghaus tudomásával jelent meg Angliában, 1849-ben. Szerzóje Alexander Keith Johnston (18041871). A Fizikai atlasz (Physical Atlas) kézi nyomással készült térképeit még kézzel színezték. A térképoldalak nagyobbak voltak, mint a Berghaus atlasz oldalai. A 30 térkép fele Johnston saját, új alkotása volt. Az atlasz 1856-ban javított, bôvített kiadásban is megjelent.

A Kozmosz elsố két kötetének a megjelenése után, 1851-ben és 1861ben Stuttgartban megjelent a címében 
Humboldt munkájára utaló atlasz, az Atlasz Humboldt Kozmoszához (Atlas zu Alexander von Humboldt's Kosmos, kiadó Krais und Hoffmann). A 34,3×29,9 cm nagyságú atlasz 39 kézi színezésû képet, térképet és 27 oldal szöveget tartalmazott. Az atlasz készítôje Traugott Bromme (18021866) felváltva hol német földön, hol Amerikában élő útikönyvíró és kiadó volt. Nem ismert, hogy volt-e kapcsolata Humboldttal. Valószínúleg nem volt, és csak felhasználta a nevét a kiadvány nagyobb bevételéért.

\section{Humboldt térképészeti munkái}

Engelmann tanulmányában (1970) összesíti az amerikai utazásról megjelent könyvekben lévô 1452 ábra között található térképek és metszetrajzok számát. Szerinte 67 felszínrajzi térkép, 98 felszíni metszetrajz (profil) és 34 földtani térkép vagy földtani metszet található a könyvsorozatban.

Az összesített adatok közül néhány érdekeset és pár máshol vagy később közzétett térképet külön kiemelünk az alábbiakban.

\section{Metszetek}

1795 A Genova és Szt. Gotthárd-hágó közötti út metszete, barometrikus mérések alapján

1799 Az Ibériai-félsziget metszete barometrikus magasságmérések és néhány helymeghatározás alapján

1799 A Pico de Teyde metszete a növényzeti előfordulások jelölésével

1802 Misszió térkép, Caura-folyó mentén

1802 A Chimborazo metszete a növényzeti zónákkal, hőmérsékleti, talajtani adatokkal

1803 Mexikó nyugat-keleti irányú földtani metszete

1853 Venezuela parti hegyláncának metszete. Amerikai földtani folyóiratban jelent meg (Leitner 2001). Térképek

1800 Az Orinoco kéziratos térképe. (2001 után jelent csak meg.)

1804, 1837 Juan de la Cosa térképének másolata és fakszimile kiadása 1804, 1809 Új-Spanyolország térképe. 1812 A Casiquiare, az Orinocót és a Rio Negrót összekötô folyó rajza
1812 Az Orinoco és az Amazonas közti terület térképe (cikkmelléklet) Guanajuato környéki bányavidék (ezüstbányák) földtani térképe

1818 Az északi félteke izotermatérképe

1820 Kuba térképe

1842 Csatornajavaslatok a Csendesés az Atlanti-óceán között. Humboldt elsônek vetette fel a közép-amerikai földszoroson keresztül vezetô csatorna létesítését. Évtizedekkel késôbb, amikor a terv megvalósíthatóvá vált, a tervezók az általa megvizsgált kilenc lehetôséget tanulmányozták és ezek közül az egyik variáns, a Panama-földszoroson keresztülvivô csatorna terve volt, amelyet végül is elfogadtak.

Humboldt útleírása, tanulmányai óriási hatással voltak kora természet- és társadalomtudományaira. Térképeinek közvetlen hatása, izotermatérképét kivéve nem volt jelentôs. A térképészet tudományát Berghaus általa is támogatott munkáján keresztül befolyásolta. Az elsố tematikus atlasz térképei új korszakot nyitottak a kartográfiában, és egy új eljárás, a térképészeti kutatási módszer kialakulását segítették. Egyes szerzók szerint, Humboldt nem értette meg, nem ismerte fel a tematikus térképek jelentôségét. Pedig a mai tematikus térképgyújtemények, elsôsorban a nemzeti atlaszok képviselik, megvalósítják, folytatják az ô kutatási elképzelését, a természeti erôk kölcsönös egymásra hatásának a vizsgálatát.

A Wikipédia Humboldt ismertetése keretében 23 foglalkozást tüntet fel, amit útja során múvelt. Ezek között szerepel a geográfus, geológus, botanikus, oceanográfus, vulkanológus, meteorológus, zoológus, mineralógus, csillagász, klimatológus és etnológus. A felsorolás majdnem a teljes földtudományt magába foglalja. Számomra hiányzik a térképész (geodéta, kartográfus) kifejezés. Remélem, hogy az előbbiekben leírtak meggyốzik az olvasót arról, hogy saját térképei, de fóleg a térképészetre tett hatása, az elsố tematikus atlasz révén elismerjük térképészként, 24. foglalkozásként is munkásságát.

\section{Irodalom}

Allen, David Y. 2014. Alexander von Humboldt and the Mapping of Mexico. e-Perimetron. Vol. 9. No. 2. pp. 78-96.

Allen, David Y. 2016. Alexander von Humboldt's critique of Aaron Arrowsmith 1810 Map of Mexico. Imago Mundi Vol. 68. No. 2. pp. 232-236. DOI: https://doi.org/10 $.1080 / 03085694.2016 .1171489$

Allen, David Y. 2017. Mapping in Humboldt's Shadow. Aaron Arrowsmith and the Cartography of Mexico, 1803-1824. Terrae Incognitae, Vol. 49. No. 1. pp. 50-67. DOI: https://doi.org/10.1080/00822884.2 017.1295599

Bulla Béla 1959. Humboldt és a magyar földrajztudomány. Földrajzi Közlemények, VII: (LXXXIII) kötet, 3. szám. pp. 193-196.

Engelmann, Gerhard 1970. Alexander von Humboldts kartographische Leistung. In Wissenschaftliche Veröffentlichungen des Geographischen Instituts der Deutschen Akademie der Wissenschaften. Neue Folge 27/82. Leipzig, S. 5-21.

Humboldt, A. V. 1857. Kozmosz, a világegyetem természeti leírása I-II. (Ford.: Fülöp Zsigmond). Athenaeum Irodalmi és Nyomdai R.-T., Pest.

Humboldt, A. V. 1861. Az Orinoco vadonában. Vál., ford., bev., jegyz., függelék Vécsey Zoltán. Gondolat, Budapest, 1967. (Világjárók. Klasszikus útleírások) p. 585

Briefwechsel Alexander von Humboldt's mit Heinrich Berghaus aus den Jahren 1825 bis 1858. Vol. 3. (Classic Reprint)

Leitner, Ulrike 2001. Unbekannte VenezuelaKarten Alexander von Humboldts. Internationale Zeitschrift für HumboldtStudien (HiN II./3), Potsdam. pp. 67-74.

Pápay Gyula 1995. A térképtudomány fejlő désének alapvonalai. (In Klinghammer István - Pápay Gyula - Török Zsolt: Kartográfiatörténet. Eötvös Kiadó, Budapest. pp. 33-135.

Radó Sándor 1959. Humboldt a geográfus (Alexander von Humboldt halálának 100. évfordulójára.) Földrajzi Közlemények, VII: (LXXXIII) kötet, 4. szám. pp. 321-341.

Robinson, A. H. - Wallis, H. 1967. Humboldt's Map of Isothermal Lines: Milestone in thematic Cartography. Cartogtaphic Journal, 4. pp. 119-123.

DOI: https://doi.org/10.1179/caj.1967.4.2.119

Wallis, H. M. - Robinson, A. H. 1987. Cartographical Innovations. An International Handbook of Mapping Terms to 1900. Map Collector Publications Ltd. p. 353

Vécsey Zoltán 1967. Alexander von Humboldt. In Humboldt, A. V.: Az Orinoco vadonában. Gondolat, Budapest. (Világjárók. Klasszikus útleírások) p. 585

Wulf, Andrea 2017. A természet feltalálója. Alexander von Humboldt kalandos élete. Park Könyvkiadó, Budapest. p. 514

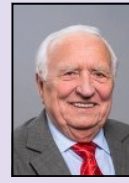

Dr. Papp-Váry Árpád professor emeritus

Budapesti Metropolitan Egyetem pappvary@t-online.hu 